\title{
Forsoning på vej 15 år efter Srebrenica
}

\section{Ivan Vejvoda}

\section{Det mest komplicerede $\mathrm{i}$ forsoningsprocessen $\mathrm{i}$ det tidligere Jugoslavien er for de enkelte lande at se deres eget ansvar for krigsforbrydelser i øjnene}

Der skulle egentlig ikke kunne blive krig i Europa igen. I årtier blev børn i skoler på tværs af kontinentet undervist i rædslerne, som nazister, fascister og kommunister havde begået som invaderende fremmede og hjemlige kollaboratører. Men på trods af alt det blev Jugoslavien i begyndelsen af 1990'erne igen skueplads for krig og slagterier, mens Europa og resten af verden så hjælpeløst til.

Historien var ikke blot ikke forbi, den kunne gentage sig selv.

Rædselsvækkende krigsforbrydelser og forbrydelser imod menneskeheden under krigene i kølvandet på Jugoslaviens sammenbrud. Alene i Bosnien-Hercegovina blev omkring 100.000 mennesker slået ihjel mellem 1992 og 1995 og mange flere såret og fordrevet. I denne katastrofe af menneskelig lidelse kom morderne fra alle sider - bosniakker, serbere og kroater - og ingen af parterne undslap, selv om bosniakkerne led mest.

Et særligt gruopvækkende blodbad står ud blandt mange: Massakren i Srebrenica i juli 1995, hvor omkring 8.000 bosniakiske mænd og drenge blev myrdet af den bosnisk serbiske hær under ledelse af Ratko Mladic. Dengang var byen en FN-garanteret sikker zone. Men den 400 mand store FN-bataljon af hollandske soldater, der havde ansvaret, viste sig ude af stand til at forhindre forbrydelserne.

Fire år sener skrev FN's daværende generalsekretær, Kofi Annan: "Srebrenica er den største skamplet i FN's historie".

\subsection{0 identificeret}

Der er gået femten år siden dette folkemord. 11. juli i år mødtes tusin- 
der af mennesker, fra udenlandske personligheder til familier til 775 nyligt identificerede Srebrenicaofre ved Memorial Center i landsbyen Potocari. (Det totale antal identificerede ofre er nu over 6.500).

Hverken det tidligere Jugoslavien eller det internationale samfund har glemt rædslerne ved disse forbrydelser. I juni 2004 publicerede Republika Srpska, den serbiske del af Bosnien-Hercegovinas to enheder, sin egen formelle efterforskningsrapport. Den er stort set glemt, men er i realiteten et godt efterforsket og detaljeret dokument om de faktiske begivenheder, og rapporten sætter navn på individuelt ansvarlige.

26. februar 2007 definerede Den Internationale Domstol (ICJ) i Haag massakren i Srebrenica som folkemord i en kendelse om en anklage fra Bosnien- Hercegovina imod den serbisk dominerede Føderationsrepublik Jugoslavien.

Kendelsen kendte ikke Beograd skyldig i folkemordet, men erklærede, at de jugoslaviske myndigheder "skulle have gjort alt, hvad der stod i deres magt for at forhindre de tragiske begivenheder".

Domstolen understregede også, at der ikke fandt folkemord sted andre steder i Bosnien-Hercegovina under konflikten 1992-95.

Serbiens demokratiske regering har ikke forholdt sig passiv, når det gælder Serbiens ansvar. Præsident Boris Tadic drog til Srebrenica til den femtende årsdag for massakren for at vise ofrene sin respekt. I marts $\mathrm{i}$ år tog parlamentet i Beograd sig sammen til at godkende Deklarationen om Srebrenica, der refererer direkte til ICJ's kendelse i februar 2007 og fordømmer krigsforbrydelserne entydigt og også den politik, der førte til dem. Deklarationen undskyldte desuden over for familierne til de myrdede bosnisk-muslimske ofre og kondolerede.

\section{Hvad med Mladic?}

Deklarationen gentager Serbiens beslutsomhed om at arrestere Ratko Mladic, som desværre er forblevet på fri fod. For to år siden arresterede Serbien Radovan Karadzic, tidligere præsident for Republika Srpska, og udleverede ham til Domstolen for Krigsforbrydelser i det Tidligere Jugoslavien (ICTY), hvor officerer ved Republika Srpskas hær tidligere er blevet dømt for folkemordet i Srebrenica. Serbien vil gøre klogt i at intensivere jagten på Mladic og således hjælpe med at indfri sine forpligtelser over for ICTY.

Konfrontationen med krigsforbrydelser, begået i en nations og dens borgeres navn, er en kompleks og langvarig proces, der må gennemføres af hensyn til forsoning, fred og demokrati. Processen har to spor.

Det første spor er international og hjemlig retfærdighed. International retfærdighed er blevet udmålt primært af ICTY og ICJ, mens hjemlig 
retfærdighed blev overladt til især krigsforbryderdomstole i Serbien, Kroatien og Bosnien-Hercegovina, der blev etableret omkring årtusindskiftet.

Det andet spor er mere kompliceret. Det går ud på, at samfundet ser sig selv i øjnene. Men hvordan kan et samfund forlige sig med forbrydelser, begået i nationens navn?

Der er historisk præcedens i Tyskland, Japan, Argentina og Spanien. De erfaringer fortæller os, at det tager tid, måske endog generationer. Det er de demokratisk valgte ledere i Sydøsteuropa, som må gennemføre forsoning og genopbygning af tillid.

Men det betyder først og fremmest at anerkende de forbrydelser, der er begået imod andre, og at være sig bevidst, at det på ingen måde formindsker de lidelser, som ens egen nation har gennemlevet. Det kræver utrættelig indsats fra staten, civilsamfundet og journalister at afdække sandheden bag krigens mest pinefulde begivenheder.

Alt dette gennemføres nu på Balkan, primært i håb om en demokratisk og fredelig fremtid i EU.

Når det gælder massakren i Srebrenica, den mest blodige enkeltbegivenhed under krigene i Jugoslavien, er det essentielt, at vi aldrig hører op med at huske den horrible forbrydelse og dens ofre.

Ivan Vejvoda er direktør for Balkan Trust for Democracy.

(C) German Marshall Fund

(Oversat fra engelsk af Vibeke Sperling). 